\title{
Treatment for sleep apnea by continuous positive airway pressure improves levels of inflammatory markers - a meta-analysis
}

Aaron Baessler ${ }^{1}$, Rashid Nadeem²,6* Michael Harvey ${ }^{1}$, Essam Madbouly², Amna Younus ${ }^{3}$, Hassan Sajid ${ }^{4}$, Jawed Naseem ${ }^{5}$, Asma Asif ${ }^{1}$ and Hasnain Bawaadam ${ }^{1}$

\begin{abstract}
Background: Obstructive sleep apnea (OSA) is associated with coronary artery disease (CAD). Intermittent hypoxia associated with OSA increases sympathetic activity and may cause systemic inflammation, which may contribute to CAD in patients with OSA. Treatment with continuous positive airway pressure (CPAP) has been shown to change levels of inflammatory markers. We analyzed data from published studies by a systematic meta-analysis.
\end{abstract}

Objective: To asses if treatment for sleep apnea by CPAP will affect levels of inflammatory markers.

Data resources: PubMed, Embase and Cochrane library.

Methods: Study eligibility criteria full text English studies of adult, human subjects, addressing values of at least one of the inflammatory markers before and after CPAP treatment. We used the definition of OSA as an apnea-hypopnea index (AHI) of $\geq 5 / h$, reported values in mean and standard deviation or median with range.

Participants: Adult, human.

Interventions: CPAP treatment for OSA.

Study appraisal and synthesis method: A total of 3835 studies were reviewed for inclusion, while 23 studies pooled for analysis. A total of 14 studies with 771 patients were pooled for C-reactive protein (CRP); 9 studies with 209 patients were pooled for tumor necrosis factor-alpha (TNF-a); and 8 studies with 165 patients were pooled for interleukin-6 (IL-6).

Endpoint definitions: The following inflammatory markers were chosen: CRP, TNF-a, and IL-6.

Results: C-reactive protein: Study level means ranged from 0.18 to $0.85 \mathrm{mg} / \mathrm{dl}$ before CPAP treatment and 0.10 to $0.72 \mathrm{mg} / \mathrm{dl}$ after CPAP treatment. Mean differences, at a study level, ranged from -0.05 to 0.50 . The pooled mean difference was 0.14 [95\% confidence interval 0.08 to $0.20, p<0.00001]$. There was heterogeneity in this endpoint ( $d f=13$, $\left.p<0.00001, I^{2}=95 \%\right)$.

Tumor necrosis factor-a: Study level means ranged from 1.40 to $50.24 \mathrm{pg} / \mathrm{ml}$ before CPAP treatment and 1.80 to $28.63 \mathrm{pg} / \mathrm{ml}$ after CPAP treatment. Mean differences, at a study level, ranged from -1.23 to 21.61. The pooled mean difference was 1.14 [95\% confidence interval 0.12 to $2.15, p=0.03$ ]. There was heterogeneity in this endpoint ( $d f=8$, $p<0.00001,12=89 \%)$.

Interleukin-6: Study level means ranged from 1.2 to $131.66 \mathrm{pg} / \mathrm{ml}$ before CPAP treatment and 0.45 to $66.04 \mathrm{pg} / \mathrm{ml}$ after CPAP treatment. Mean differences, at a study level, ranged from -0.40 to 65.62 . The pooled mean difference (Continued on next page)

\footnotetext{
* Correspondence: rashid.nadeem@va.gov

2Pulmonary and Sleep Medicine, James A Lovell Federal Health Care Center,

North Chicago, IL, USA

${ }^{6}$ James A. Lovell Federal Health Care Centre, 3001 Green Bay Road, North

Chicago, IL 60064, USA

Full list of author information is available at the end of the article
} 


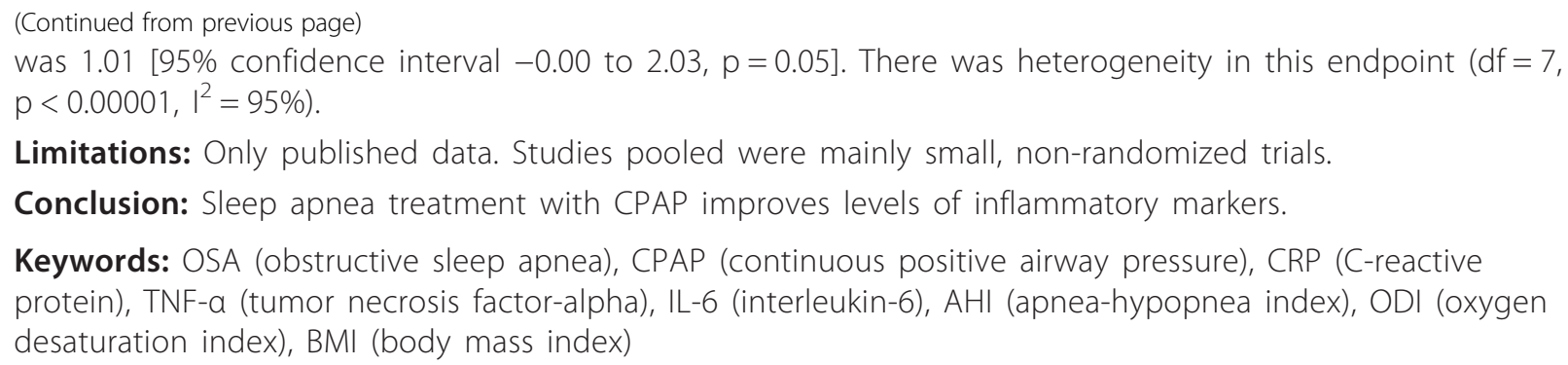

\section{Introduction}

Obstructive sleep apnea (OSA) is a common disorder affecting about $4 \%$ of middle-aged males and $2 \%$ of middle-aged females in the developed world [1] and is a significant source of morbidity and mortality [2]. OSA is characterized by recurrent episodes of upper airway collapses during sleep. These recurrent episodes of upper airway collapse usually are accompanied by oxyhemoglobin desaturation and terminated by brief arousals which result in marked sleep fragmentation and chronic excessive daytime sleepiness (EDS) [1,3]. As a result, there is an increased expression of systemic inflammatory markers, a sustained activation of the sympathetic nervous system [4], and derangement in endothelial function [5]. Many of these physiologic and biochemical abnormalities are implicated in the pathogenesis of cardiovascular and cerebrovascular diseases, as ongoing inflammatory responses play important roles in atherosclerosis $[6,7]$. OSA has been increasingly linked to cardiovascular and cerebrovascular disease [8,9] and many studies have shown that OSA is associated with increased cardiovascular and cerebrovascular morbidity [10-14].

The literature suggests that an inflammatory etiology, in addition to mechanical factors, may contribute to the pathogenesis of OSA, as surgical biopsies of the uvula in patients with OSA have demonstrated histological abnormalities, including subepithelial edema and excessive inflammatory cell infiltration $[15,16]$. Also, the overexpression of interleukin-8 (IL-8) in human bronchial epithelial cells in response to a vibratory stimulus generated by snoring has been implicated to the pathogenesis of OSA [17]. Many studies have reported that patients with OSA have increased levels of mediators of the systemic inflammatory response, including cell adhesion molecules (ICAM), coagulation factors (Factor VIII, Tissue factor), and C-reactive protein (CRP) [18-20]. Proinflammatory cytokines are also up-regulated in patients with OSA [21-23]. In particular, significant elevations in serum levels of tumor necrosis factor- $\alpha$ (TNF- $\alpha$ ), interleukin-1 $\beta$ (IL-1 $\beta$ ), and interleukin-6 (IL-6) have been seen in patients with OSA [18,24-29]. However, some studies did not show elevation of CRP in patients with OSA [30,31].
CRP is an important serum marker of inflammation. It is synthesized from the liver and is largely under the regulation of the pro-inflammatory cytokine IL-6 [32-34]. IL-6 is believed to represent the major regulator of the hepatic acute phase response [33,34]. Unlike cytokines, CRP levels are quite stable in the same individual across 24 hours and may reflect the level of inflammatory response [35].

CRP may play a direct role in the initiation and progression of atherosclerosis [36]. Its pro-inflammatory and proatherogenic properties have been found in endothelial cells [37], vascular smooth muscle cells [38], and monocytemacrophages [39]. CRP levels are also associated with oxidative stress [40]. Epidemiological studies have shown that an elevated CRP level in the high-normal $(0.2$ to $1.5 \mathrm{mg} / \mathrm{dl})$ range in apparently healthy men and women is a strong predictor of cardiovascular risk [41-43]. In patients with acute coronary artery disease, stable angina pectoris, and a history of myocardial infarction, higher levels of CRP are also associated with future cardiovascular events $[44,45]$.

IL-6 is a circulating cytokine known to be secreted from a number of different cells, including activated macrophages and lymphocytes [46]. Inflammation is the main stimulus for IL-6 production, but other stimuli also exist, such as cigarette smoke [46] and adiposity [47].

TNF- $\alpha$ is a pro-inflammatory cytokine that has a significant role in host defense and also mediates the pathogenesis of a number of disease processes, including atherosclerosis, septic shock, and auto-immune disorders [48]. TNF- $\alpha$ has two transmembrane-bound receptors and soluble forms that are released by proteolysis of the cell-bound receptor under the control of other inflammatory cytokines (e.g., IL-6, IL-2, IFN- $\gamma$ ), T cell activation, and by TNF-.alpha; itself $[48,49]$.

Hypoxemia results in increases in IL-6 and CRP in normal humans [50]. Sleep fragmentation and deprivation also induces an increase in cytokines that may underlie inflammatory responses, which lead to cardiovascular morbidity $[20,30]$. OSA results in repetitive and severe nocturnal hypoxemia and sleep disturbances $[1,3,51]$.

Continuous positive airway pressure (CPAP) is the primary treatment for OSA [52], since it eliminates upper airway collapse during sleep and improves sleep 
fragmentation, daytime symptoms [53], and quality of life [54]. Evidence shows that CPAP therapy reduces cardiovascular morbidity and risk [11,55], There are many studies with small sample sizes and few with larger sample sizes which address the effect of CPAP therapy on cardiovascular profiles and serum inflammatory markers. Therefore, we performed a metaanalysis to study the effects of CPAP on the serum inflammatory markers CRP, IL-6, and TNF- $\alpha$.

\section{Objectives}

We aim to assess the effect of CPAP treatment on inflammatory markers in human subjects with sleep apnea by comparing levels of inflammatory markers before and after specified treatment in all available published studies.

\section{Methods}

\section{Studies and endpoint definitions}

PRISMA guidelines were followed to perform this metaanalysis. PICOS format was followed; P: inflammatory markers (CRP, TNF- $\alpha$, and IL-6), I: CPAP treatment, C; levels of markers before and after treatment period, $\mathrm{O}$ : decrease in marker levels. Inflammatory markers were chosen based on a review of the literature. The following inflammatory markers were chosen: CRP, TNF- $\alpha$, and IL-6. Inclusion criteria for the subsequent study selection were as follows: 1) the study must have been in English; 2) full text manuscripts had to be available; 3) the study must have reported values for at least one of the markers of interest, both before and after CPAP treatment (4 weeks to 12 months after beginning treatment); 4) OSA was strictly defined as AHI of $\geq 5 / h$ measured by polysomnography; 5) the study must have reported values in mean and standard deviation or median with range; 6) the patient number for all groups must have been reported; 7) the study must have been performed on adult ( $>18$ years of age) humans.

\section{Data source and study selection}

Studies for review were found by searching the PubMed and Cochrane databases with a duration from January 01, 1960 to December $31^{\text {st }}$, 2011. Embase was also searched with the same criteria in order to identify additional studies. Unpublished data from scientific meetings were not searched, since most abstracts do not provide enough data needed for meta-analyses. Searches were conducted using different combinations of the following key words: sleep apnea, inflammatory markers, C-reactive protein, tumor necrosis factor- $\alpha$, interleukin- 6 , continuous positive airway pressure, autoadjusting positive airway pressure, and pressure therapy. In order to ensure that relevant sources were not left out, each marker or therapy was searched in its abbreviated form using the same word combinations as before. Multiple authors individually searched for and scored manuscripts for inclusion. Manuscripts were scored in duplicates, and if a manuscript was scored differently by two authors, then that manuscript was reviewed by a third author to finalize inclusion. The quality of studies was ranked according to the Sackett et al's hierarchy of evidence [56] (Table 1).

\section{Data extraction and statistical analysis}

Data was extracted from each study by a single author and then reviewed by a second author to ensure that no errors were made. Serum levels of inflammatory markers before and after CPAP treatment were extracted from studies as the mean with standard deviation. For studies in which data was reported in median and interquartile range, mean and standard deviation were calculated utilizing methods described by Hozo et al. [57].

Only our target variables (inflammatory markers) were recorded since we did not plan to do subgroup analyses

Table 1 Quality of evidence: number and level of evidence of peer-reviewed and published papers

\begin{tabular}{|c|c|c|}
\hline \multicolumn{3}{|c|}{ Hierarchy of evidence } \\
\hline Level of evidence & Description & No. of studies \\
\hline $1 \mathrm{a}$ & Systemic review (with homogeneity*) of randomized, controlled clinical trials (RCTs) & 0 \\
\hline $1 \mathrm{~b}$ & Individual randomized controlled clinical trial (RCT) (with narrow Confidence Intervalł) & 0 \\
\hline $1 \mathrm{c}$ & All or none case series & 0 \\
\hline $2 \mathrm{a}$ & Systemic review (with homogeneity*) of cohort studies & 0 \\
\hline $2 \mathrm{~b}$ & Individual cohort study (including low quality RCT; e.g., <80\% follow-up) & 0 \\
\hline $2 \mathrm{c}$ & "Outcomes" Research; Ecological studies & 0 \\
\hline 3 a & Systemic review (with homogeneity*) of case-control studies & 0 \\
\hline $3 \mathrm{~b}$ & Individual Case-control Study & 23 \\
\hline 4 & Case-series (and poor quality cohort and case-control studies) & 0 \\
\hline 5 & Expert opinion without explicit critical appraisal, or based on physiology, bench research or "first principles" & 0 \\
\hline Others & Letters to editor, Abstract & 0 \\
\hline
\end{tabular}


or meta-regression. Studies that used CPAP or APAP were included in our review. If studies included data from both CPAP and APAP treatment, the each set of data was included in the meta-analysis as a separate study. For example, Patruno et al. [58] utilized both CPAP and APAP treatments. If a study involved the removal CPAP and its effects on inflammatory markers, we excluded the study from our meta-analysis. For example, Phillips et al. [59] measured the effect of short-term withdrawal from CPAP on levels of vascular inflammatory markers. The risk for bias was assessed at a study level and an outcome level. To minimize the effect of bias by including non-compliant patients, we only included compliant patients, utilizing a compliance definition of CPAP usage $\geq 4$ hours on at least $70 \%$ of nights when reported by the manuscript. We also excluded the studies if OSA was not diagnosed by measured by polysomnography. For example Kohler 2009 was excluded since OSA was defined by Oxygen Desaturation Index instead of AHI. Some studies that fulfilled our inclusion criteria had to be excluded because values of inflammatory markers were exponentially larger than the values for the same inflammatory marker in all other studies. Tamaki et al. [60], for example, measured the production of TNF- $\alpha$ by monocytes before and after treatment with CPAP, and the values, when converted, were 1000 times greater than the other studies measuring TNF- $\alpha$ levels. Intercellular adhesion molecule (ICAM) and interleukin-8 (IL-8) were not included in this meta-analysis because there were not enough studies available to performed metaanalysis. Moreover oxyhemoglobin desaturation data was not included for the same reason. For studies in which no numerical data accompanied the graphical data, the authors were contacted in order to obtain the data. Authors of one study produced two independent papers that included the same CPAP and inflammatory markers data, so we only included the data from Schiza et al. 2010 [61] and not from Mermigkis et al. 2011 [62].

Statistical analyses were done using RevMan software version 5. Pooled mean difference was calculated using a random effects model for all outcomes due to the high level of heterogeneity present. Heterogeneity was assessed by calculating the Cochrane Q statistic. $\mathrm{I}^{2}$ statistics were also calculated to help quantify the amount of heterogeneity. An $\mathrm{I}^{2}$ of the following percentages represents different levels of heterogeneity: 25-49\% low, 50-74\% moderate, and 75-100\% high. Measurement units of inflammatory markers we used in the meta-analysis were $\mathrm{mg} / \mathrm{dl}$ for CRP and $\mathrm{pg} / \mathrm{ml}$ for IL-6 and TNF- $\alpha$. If values of any of these markers were not reported in the same standard measurement unit we used, the values were converted to the appropriate unit. Primary principal measures were differences in means of inflammatory markers before and after CPAP treatment.

\section{Results}

A total of 3835 studies were reviewed for inclusion with 23 studies pooled for analysis. The quality of evidence was low (3B-individual case-control study) for all 23 studies. A total of 14 studies with 771 patients were pooled for CRP; 9 studies with 209 patients were pooled for TNF- $\alpha$; and 8 studies with 165 patients were pooled

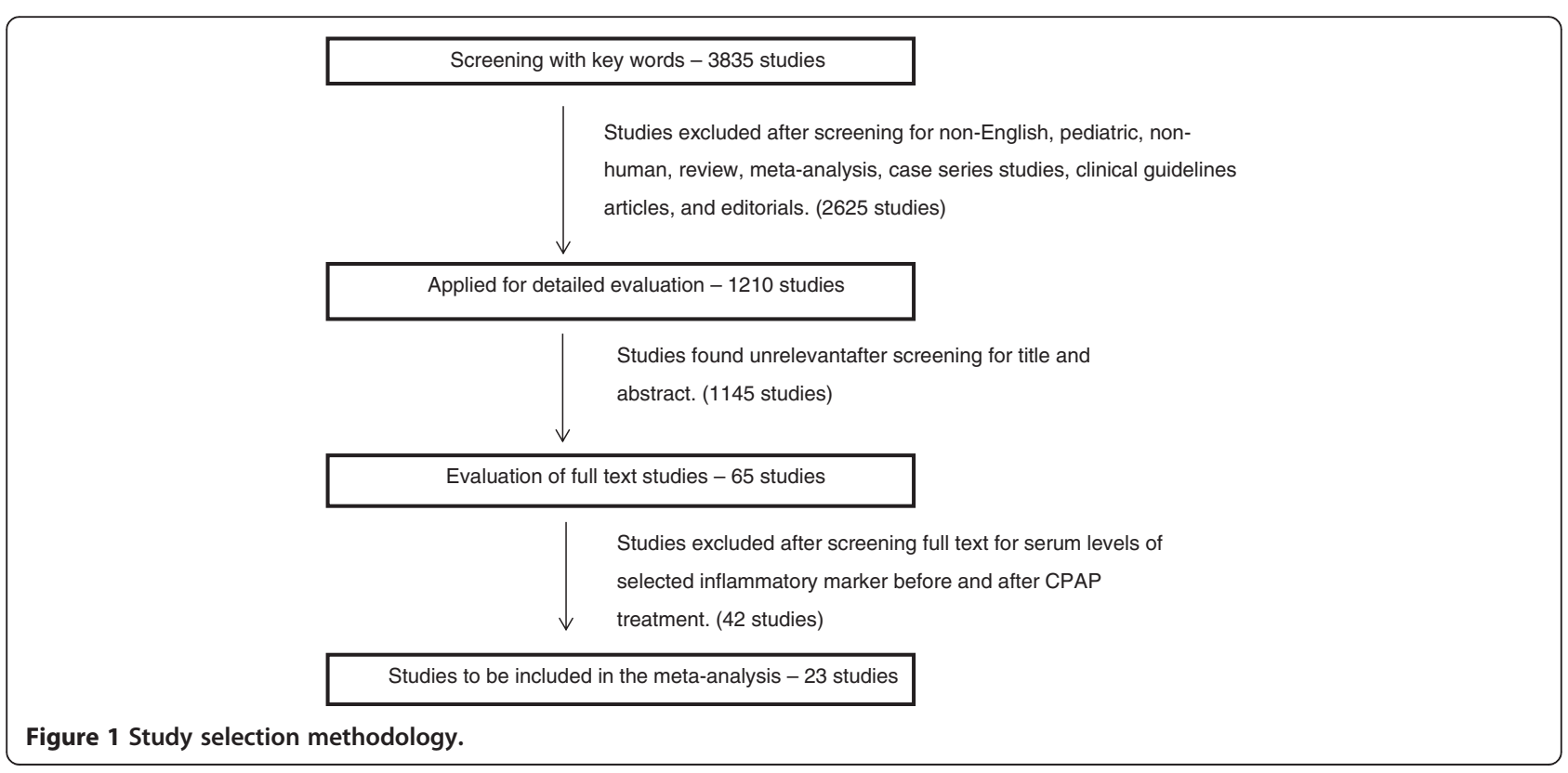


Table 2 Selected studies measuring serum CRP before and after CPAP

\begin{tabular}{|c|c|c|c|c|c|}
\hline Study & Study design & Study population characteristics & OSA definition & Minimum CPAP usage & Outcome \\
\hline Carniero et al. 2009 [63] & Case-control & 7 severely obese men & $\mathrm{AHI}>30$ & $\geq 5 \mathrm{~h} /$ day for 3 months & No significant change \\
\hline Chung et al. 2011 [64] & Case-control & 25 total: 22 men, 3 women & $\mathrm{AHI} \geq 15$ & $\geq 4$ h/day for 3 months & No significant change \\
\hline Colish et al. 2012 [65] & Case-control & 47 total: 32 men, 15 women; 25 obese, 22 overweight & $\mathrm{AHI} \geq 15$ & $\geq 4.5 \mathrm{~h} /$ day for 12 months & No significant change \\
\hline Dorkova et al. 2008 [66] & Case-control & 16 total: 15 men, 1 woman & $\mathrm{AHI} \geq 30$ & $\geq 4$ h/day for 8 weeks & No significant change \\
\hline Harsch et al. 2004 [67] & Case-control & 20 obese patients & $\begin{array}{l}\mathrm{AHI}=48.6 \pm 9.1 \\
\quad(\text { mean } \pm \mathrm{SD})\end{array}$ & $\begin{array}{c}5.32 \pm 0.67 \mathrm{~h} / \text { day } \\
\text { (mean } \pm \text { SD) for } 8 \text { weeks }\end{array}$ & No significant change \\
\hline lesato et al. 2007 [68] & Case-control & 36 total & $\mathrm{AHI} \geq 20$ & $\geq 4$ h/day for 3 months & Significantly decreased \\
\hline Ishida et al. 2009 [69] & Case-control & 40 total: 32 men, 8 women & $\mathrm{AHI}>20$ & $>4 \mathrm{~h} /$ day, $5 \mathrm{~d} /$ week for 6 months & Significantly decreased \\
\hline Patruno et al. 2007 [58] (APAP) & Case-control & 15 total & $\mathrm{AHI}>20$ & $>4 \mathrm{~h} /$ day for 3 months & Significantly decreased \\
\hline Patruno et al. 2007 [58] (CPAP) & Case-control & 16 total & $\mathrm{AHI}>20$ & $>4$ h/day for 3 months & Significantly decreased \\
\hline Ryan et al. 2007 [70] & Case-control & 49 total & $\mathrm{AHI}>15$ & $>4 \mathrm{~h} /$ day for 6 weeks & No significant change \\
\hline Schiza et al. 2010 [61] & Case-control & 436 total: 252 men, 184 women & $\mathrm{AHI}>15$ & $>4 \mathrm{~h} /$ day, $5 \mathrm{~d} /$ week for 12 months & Significantly decreased \\
\hline Steiropoulos et al. 2007 [71] & Case-control & 20 total: 16 men, 4 women & $\mathrm{AHI}>15$ & $\geq 4 \mathrm{~h} /$ night for 6 months & Significantly decreased \\
\hline Yokoe et al. 2003 [18] & Case-control & 17 total & $\mathrm{AHI} \geq 20$ & 1 month & Significantly decreased \\
\hline Zhao et al. 2011 [72] & Case-control & 27 total & $\mathrm{AHI} \geq 30$ & Good compliance for 3 months & Significantly decreased \\
\hline
\end{tabular}


Table 3 Selected studies measuring serum TNF- $a$ before and after CPAP

\begin{tabular}{|c|c|c|c|c|c|}
\hline Study & Study design & $\begin{array}{c}\text { Study population } \\
\text { characteristics }\end{array}$ & OSA definition & Minimum CPAP usage & Outcome \\
\hline Arias et al. 2008 [73] & Cross-over & 25 men & $\mathrm{AHI} \geq 10$ & $\geq 3.5 \mathrm{~h} /$ day for 3 months & No significant change \\
\hline Carniero et al. 2009 [63] & Case-control & 7 severely obese men & $\mathrm{AHI}>30$ & $\geq 5$ h/day for 3 months & Decreased, not significant \\
\hline Guasti et al. 2009 [74] & Case-control & 16 total & $\mathrm{AHI}>20$ & Good compliance for 12 weeks & No significant change \\
\hline Minoguchi et al. 2004 [25] & Case-control & 12 total & $\mathrm{AHI} \geq 20$ & $>4.5 \mathrm{~h} /$ day for 1 month & Significantly decreased \\
\hline Ryan et al. 2005 [75] & Case-control & 19 total & $\mathrm{AHI} \geq 20$ & 4.4 h/day (mean) for 6 weeks & Significantly decreased \\
\hline Ryan et al. 2006 [76] & Case-control & 49 men & $\mathrm{AHI}>5$ & Compliant for 6 weeks & Significantly decreased \\
\hline Steiropoulos et al. 2009 [77] & Case-control & 32 total & $\mathrm{AHI}>5$ & $\geq 4$ h/day for 6 months & Significantly decreased \\
\hline Tamaki et al. 2009 [60] & Case-control & $\begin{array}{c}33 \text { total: } 30 \text { males, } \\
3 \text { females }\end{array}$ & $\mathrm{AHI} \geq 10$ & 3 months (no compliance data) & Significantly decreased \\
\hline Vgontzas et al. 2008 [78] & Case-control & 16 total & $\mathrm{AHI}>5$ & $\geq 4 \mathrm{~h} /$ day, $\geq 5 \mathrm{~d} /$ week for 3 months & No significant change \\
\hline
\end{tabular}

for IL-6 (Figure 1). The studies measuring key serum inflammatory markers are outlined in Tables 2, 3 and 4.

\section{C-reactive protein}

With respect to CRP, study level means ranged from 0.18 to $0.85 \mathrm{mg} / \mathrm{dl}$ before CPAP treatment and 0.10 to $0.72 \mathrm{mg} / \mathrm{dl}$ after CPAP treatment. Mean differences, at a study level, ranged from -0.05 to 0.50 . The pooled mean difference was 0.14 [95\% confidence interval 0.08 to $0.20, \mathrm{p}<0.00001]$. There was heterogeneity in this endpoint $\left(\mathrm{df}=13, \mathrm{p}<0.00001, \mathrm{I}^{2}=95 \%\right.$ ) (Figure 2).

\section{Tumor necrosis factor- $a$}

With respect to TNF- $\alpha$, study level means ranged from 1.40 to $50.24 \mathrm{pg} / \mathrm{ml}$ before CPAP treatment to 1.80 to $28.63 \mathrm{pg} / \mathrm{ml}$ after CPAP treatment. Mean differences, at a study level, ranged from -1.23 to 21.61 . The pooled mean difference was 1.14 [95\% confidence interval 0.12 to $2.15, \mathrm{p}=0.03$ ]. There was heterogeneity in this endpoint $\left(\mathrm{df}=8, \mathrm{p}<0.00001, \mathrm{I}^{2}=89 \%\right.$ ) (Figure 3 ).

\section{Interleukin-6}

Study level means ranged from 1.2 to $131.66 \mathrm{pg} / \mathrm{ml}$ before CPAP treatment and 0.45 to $66.04 \mathrm{pg} / \mathrm{ml}$ after CPAP treatment. Mean differences, at a study level, ranged from -0.40 to 65.62 . The pooled mean difference was 1.01 [95\% confidence interval 0.00 to 2.03 , $\mathrm{p}=0.05]$. There was heterogeneity in this endpoint $(\mathrm{df}=7$, $\mathrm{p}<0.00001, \mathrm{I}^{2}=95 \%$ ) (Figure 4).

\section{Discussion}

The present meta-analysis showed that CPAP therapy improves serum levels of the inflammatory markers CRP, TNF- $\alpha$, and IL-6. Using a p-value of $<0.05$ to mark a significant change, the levels of CRP and TNF- $\alpha$ were significantly decreased, whereas the levels of IL-6 showed no significant change. IL-6 levels did, however, show a general trend of decreasing values with CPAP usage.

With respect to CRP, the following studies agreed that CPAP usage significantly decreases serum levels of CRP: Iesato et al. 2007 [68], Ishida et al. 2009 [69], Patruno et al. 2007 [58], Schiza et al. 2010 [61], Steiropoulos et al. 2007 [71], Yokoe et al. 2003 [18], and Zhao et al. 2011 [72]. With respect to TNF- $\alpha$, the following studies agreed that CPAP usage significantly decreases serum levels of TNF- $\alpha$ : Minoguchi et al. 2004 [25], Ryan et al. 2005 [75], Ryan et al. 2006 [76], Steiropoulos et al. 2009 [77], and Tamaki et al. 2006 [60]. With respect to IL-6, the following studies agreed that

Table 4 Selected studies measuring serum IL-6 before and after CPAP

\begin{tabular}{cccccc}
\hline Study & Study design & $\begin{array}{c}\text { Study population } \\
\text { characteristics }\end{array}$ & OSA definition & Minimum CPAP usage & Outcome \\
\hline Arias et al. 2008 [73] & Cross-over & 25 men & AHI $\geq 10$ & $\geq 3.5$ h/day for 3 months & No significant change \\
Burioka et al. 2008 [79] & Case-control & 9 total & AHI $>30$ & 5 h/day (mean) for 3 months & Significantly decreased \\
Carniero et al. 2009 [63] & Case-control & 7 severely obese men & AHI $>30$ & $\geq 5$ h/day for 3 months & No significant change \\
Ryan et al. 2006 [76] & Case-control & 49 men & AHI $>5$ & Compliant for 6 weeks & No significant change \\
Steiropoulos et al. 2009 [77] & Case-control & 32 total & AHI $>5$ & $\geq 4$ h/day for 6 months & No significant change \\
Vgontzas et al. 2008 [78] & Case-control & 16 total & AHI $>5$ & $\geq 4$ h/day, $\geq 5$ d/week for 3 months & No significant change \\
Ye et al. 2010 [80] & Case-control & 10 total & AHI $\geq 20$ & $>4$ h/day for 6 months & Significantly decreased \\
Yokoe et al. 2003 [18] & Case-control & 17 total & AHI $\geq 20$ & 1 month & Significantly decreased \\
\hline
\end{tabular}




\begin{tabular}{|c|c|c|c|c|c|c|c|c|c|c|}
\hline \multirow[b]{2}{*}{ Study or Subgroup } & \multicolumn{3}{|c|}{ CRP before CPAP } & \multicolumn{3}{|c|}{ CRP after CPAP } & \multirow[b]{2}{*}{ Weight } & \multirow{2}{*}{$\begin{array}{l}\text { Mean Difference } \\
\text { IV, Random, } 95 \% \mathrm{Cl}\end{array}$} & \multirow{2}{*}{\multicolumn{2}{|c|}{$\begin{array}{c}\text { Mean Difference } \\
\text { IV, Random, } 95 \% \mathrm{Cl}\end{array}$}} \\
\hline & Mean & SD & Total & Mean & SD & Total & & & & \\
\hline Carneiro et al 2009 & 0.85 & 0.29 & 7 & 0.72 & 0.34 & 7 & $2.3 \%$ & $0.13[-0.20,0.46]$ & & \\
\hline Chung et al 2011 & 0.61 & 1.52 & 25 & 0.33 & 0.88 & 25 & $0.6 \%$ & $0.28[-0.41,0.97]$ & & \\
\hline Dorkova et al 2008 & 0.387 & 0.37 & 16 & 0.279 & 0.211 & 16 & $4.5 \%$ & $0.11[-0.10,0.32]$ & & + \\
\hline Harsch et al 2004 & 0.278 & 0.086 & 20 & 0.285 & 0.079 & 20 & $11.4 \%$ & $-0.01[-0.06,0.04]$ & & 1 \\
\hline lesato et al 2007 & 0.1774 & 0.0278 & 36 & 0.0999 & 0.021 & 36 & $12.5 \%$ & $0.08[0.07,0.09]$ & & $=$ \\
\hline Ishida et al 2009 & 0.23 & 0.04 & 40 & 0.16 & 0.03 & 40 & $12.5 \%$ & $0.07[0.05,0.09]$ & & 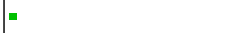 \\
\hline Patruno et al 2007 CPAP & 0.8 & 0.3 & 16 & 0.46 & 0.38 & 16 & $3.8 \%$ & $0.34[0.10,0.58]$ & & - \\
\hline Ryan et al 2007 & 0.25 & 0.2059 & 49 & 0.305 & 0.316 & 49 & $8.6 \%$ & $-0.05[-0.16,0.05]$ & & \\
\hline Schiza et al 2010 & 0.79 & 0.66 & 436 & 0.29 & 0.32 & 436 & $10.5 \%$ & $0.50[0.43,0.57]$ & & - \\
\hline Steiropoulos et al 2007 & 0.72 & 0.54 & 20 & 0.55 & 0.47 & 20 & $2.5 \%$ & $0.17[-0.14,0.48]$ & & \\
\hline Yokoe et al 2003 & 0.29 & 0.02 & 17 & 0.11 & 0.03 & 17 & $12.4 \%$ & $0.18[0.16,0.20]$ & & - \\
\hline Zhao et al 2011 & 0.418 & 0.326 & 27 & 0.227 & 0.242 & 27 & $6.4 \%$ & $0.19[0.04,0.34]$ & & - \\
\hline Total $(95 \% \mathrm{Cl})$ & & & 771 & & & 771 & $100.0 \%$ & $0.14[0.08,0.20]$ & & $\diamond$ \\
\hline \multicolumn{7}{|c|}{$\begin{array}{l}\text { Heterogeneity: } \mathrm{Tau}^{2}=0.01 ; \mathrm{Chi}^{2}=273.64, \mathrm{df}= \\
\text { Test for overall effect: } Z=4.95(\mathrm{P}<0.00001)\end{array}$} & & & $\begin{array}{ccc} & 1 & 1 \\
-1 & -0.5 & 0 \\
\text { Lower level without CPAP }\end{array}$ & $\begin{array}{|cc|} & 1 \\
0.5 & 1 \\
\text { Lower level with CPAP }\end{array}$ \\
\hline
\end{tabular}

CPAP usage significantly decreases serum levels of IL-6: Burioka et al. 2008 [79], Ye et al. 2010 [80], and Yokoe et al. 2003 [18].

We also examined why some studies did not agree with our overall finding that CPAP significantly improves levels of inflammatory markers. With regards to CRP, Carniero et al. 2009 [63] showed there was no significant change in the levels of CRP after CPAP, and this could possibly be due to the small sample population (7 subjects) of the study. Chung et al. 2011 [64], Dorkova et al. 2008 [66], Harsch et al. 2004 [67], and Ryan and colleagues [70] showed no significant change in serum CRP levels, possibly because of the small sample populations $(25,16$, and 20 , respectively) and possibly because there was no significant weight reduction among the patients in the study. There is some debate on whether CRP levels are dependent on obesity or the severity of OSA $[31,81]$. Kohler and colleagues [82] performed a randomized controlled trial and similarly concluded that 4 weeks of CPAP had no significant reduction in CRP levels, possibly due to the fact that many of the subjects also had a number of other comorbidities in addition to OSA.
Five of the nine studies measuring TNF- $\alpha$ levels showed that CPAP usage significantly decreases serum levels of TNF- $\alpha$ [25,60,75-77]. Studies that showed no significant change in TNF- $\alpha$ were examined to determine why those studies did not agree with our overall findings. Carniero et al. 2009 [63] had a very small sample population (7) and showed that CPAP usage over 3 months decreases serum TNF- $\alpha$, though not significantly. Guasti et al. 2009 [74] also had a small sample population (only 16) and many of the patients had other comorbidities, such as elevated BMI. In addition to a small sample population (16) and patients having high BMIs, Vgontzas and colleagues [78] noted that there were discrepancies in the compliance of the patients using CPAP. Only 10 of the patients used CPAP for more than 4 hours per night.

With respect to IL-6, only three of nine studies showed that CPAP usage decreases serum levels of IL-6 $[18,79,80]$. The rest of studies examined showed no significant change in serum IL-6 after CPAP treatment. Again, these studies all had populations under 50 people, and the patients also exhibited comorbidities, like obesity. A few of these studies $[18,76,82]$ only measured the

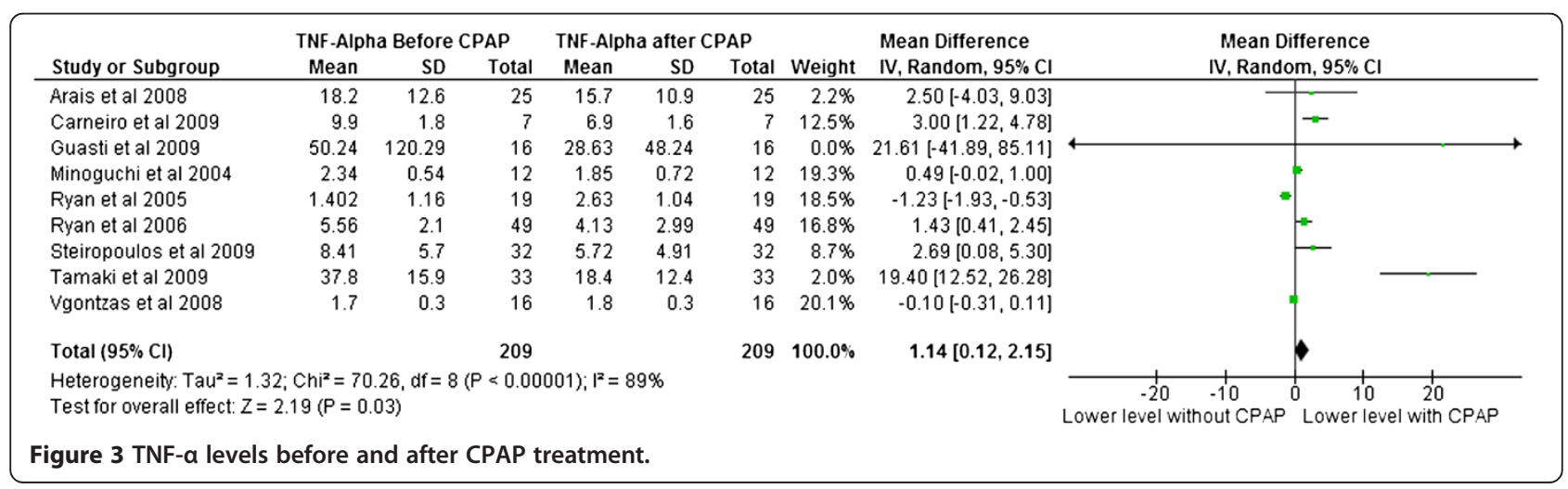




\begin{tabular}{|c|c|c|c|c|c|c|c|c|c|}
\hline \multirow[b]{2}{*}{ Study or Subgroup } & \multicolumn{3}{|c|}{ IL-6 before CPAP } & \multicolumn{3}{|c|}{ IL-6 after CPAP } & \multirow[b]{2}{*}{ Weight } & \multirow{2}{*}{$\begin{array}{l}\text { Mean Difference } \\
\text { IV, Random, } 95 \% \mathrm{Cl}\end{array}$} & \multirow{2}{*}{$\begin{array}{l}\text { Mean Difference } \\
\text { IV, Random, } 95 \% \mathrm{CI}\end{array}$} \\
\hline & Mean & SD & Total & Mean & SD & Total & & & \\
\hline Arias et al 2008 & 4.3 & 3.5 & 25 & 4.7 & 2 & 25 & $12.5 \%$ & $-0.40[-1.98,1.18]$ & T \\
\hline Burioka et al 2008 & 6.2 & 1 & 9 & 3.4 & 0.4 & 9 & $16.6 \%$ & $2.80[2.10,3.50]$ & - \\
\hline Carneiro et al 2009 & 3.5 & 0.65 & 7 & 2.8 & 0.72 & 7 & $16.5 \%$ & $0.70[-0.02,1.42]$ & 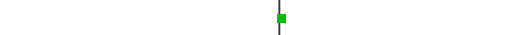 \\
\hline Ryan et al 2006 & 5.13 & 22.65 & 49 & 4.46 & 16.39 & 49 & $1.5 \%$ & $0.67[-7.16,8.50]$ & + \\
\hline Steiropoulos et al 2009 & 2.71 & 1.27 & 32 & 2.46 & 1.08 & 32 & $17.0 \%$ & $0.25[-0.33,0.83]$ & 1 \\
\hline Vgontzas et al 2008 & 4.5 & 0.7 & 16 & 4.7 & 0.7 & 16 & $17.3 \%$ & $-0.20[-0.69,0.29]$ & I \\
\hline Ye et al 2010 & 131.66 & 20.39 & 10 & 66.04 & 10.04 & 10 & $0.5 \%$ & $65.62[51.53,79.71]$ & \\
\hline Yokoe et al 2003 & 1.2 & 0.15 & 17 & 0.45 & 0.08 & 17 & $18.0 \%$ & $0.75[0.67,0.83]$ & 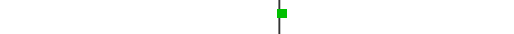 \\
\hline \multicolumn{3}{|l|}{ Total $(95 \% \mathrm{Cl})$} & 165 & & & 165 & $100.0 \%$ & $1.01[-0.00,2.03]$ & 1 \\
\hline \multicolumn{8}{|c|}{$\begin{array}{l}\text { Heterogeneity: } \operatorname{Tau}^{2}=1.48 ; \mathrm{Chi}^{2}=133.68, \mathrm{df}=7(\mathrm{P}<0.00001) ; \mathrm{I}^{2}=95 \% \\
\text { Test for overall effect: } Z=1.96(\mathrm{P}=0.05)\end{array}$} & & 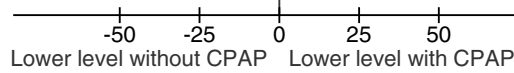 \\
\hline
\end{tabular}

effect of CPAP on systemic inflammation over 4-6 weeks, which is relatively short compared to many of the other studies examined.

There are a few limitations of this meta-analysis. It is very clear that the available literature is largely low-level evidence. Most of the studies included in the metaanalysis have examined the confounding factors (age, AHI, BMI), which we did not adjust, since we did not perform a meta-regression analysis. Moreover we did not perform the subgroups analysis to examine effect of severity of OSA on inflammatory markers before or after treatment. There are number of studies available in which levels of these markers were measured in patients with OSA and controls. Those studies cannot be included because of significant methodological differences (no CPAP). We performed a metaregression analysis on this larger pool of studies (submitted to JCSM being reviewed). Also, we did not account for CPAP compliance rates. If we had included the data from non-compliant CPAP groups, the serum levels of the selected inflammatory markers may have been affected. Another potential limitation is that we excluded all papers written in languages other than English, which could raise the possibility of publication bias. We have excluded some studies with exponentially high values when compared to the other studies in this meta-analysis. Including those studies could affect the net result of the meta-analysis. We were not able to retrieve the numerical data from some studies that reported data only in graphical form. That data inclusion could have affected the results of our meta-analysis. It is known that studies with positive results tend to get published while studies with negative results are less likely to be published, and we only included data from published studies in our metaanalysis. This could have led to publication bias as well.

Despite all these variations, it was reassuring that in majority of the studies (regardless of the composition of the study) those with CPAP treatment have lower levels of systemic inflammatory markers. This suggests that selection and sampling biases were unlikely to be responsible for the observed associations. The improvement in inflammatory markers suggests that OSA treatment modulates the cardiovascular risk profile through multiple mechanisms, including inflammation, which may play an important role for the development of atherosclerosis. Further studies are required to explore this dimension of the cardiovascular risk profile, such as the impact of OSA treatment on atherosclerosis and vasculopathy.

In conclusion, CPAP usage for patients with OSA significantly decreases serum inflammatory markers CRP and TNF- $\alpha$. Also, CPAP usage seems to decrease serum levels of IL-6.

\section{Competing interests}

All authors declare that they have no competing interests.

\section{Authors' contributions}

$A Y, H S, A A, H B$, performed searches and scoring of manuscripts. RN, EM, MH, $A B$, and $J N$ participated in conception of aim, scoring manuscripts and writing manuscript. $\mathrm{AB}, \mathrm{MH}, \mathrm{RN}, \mathrm{JN}$ and $\mathrm{AA}$ and $\mathrm{HB}$ performed data extraction and data double check. RN, JN performed data analysis and interpretation. All authors read and approved the final manuscript.

\section{Acknowledgement}

We thank Dr. Mohita Kumar for providing help with some data collection.

\section{Author details}

${ }^{1}$ Rosalind Franklin University of Medicine and Science, Chicago Medical School, North Chicago, IL, USA. ${ }^{2}$ Pulmonary and Sleep Medicine, James A Lovell Federal Health Care Center, North Chicago, IL, USA. ${ }^{3}$ Bahria University medical and dental college, Karachi, Pakistan. ${ }^{4}$ McMaster University, Ontario, Canada. ${ }^{5}$ University of Karachi, Karachi, Pakistan. ${ }^{6}$ James A. Lovell Federal Health Care Centre, 3001 Green Bay Road, North Chicago, IL 60064, USA.

Received: 6 September 2012 Accepted: 5 March 2013 Published: 22 March 2013

\section{References}

1. Young T, Palta M, Dempsey J, Skatrud J, Weber S, Badr S: The occurrence of sleep-disordered breathing among middle-aged adults. N Engl J Med 1993, 32:1230-1235.

2. Young T, Skatrud J, Peppard PE: Risk factors for obstructive sleep apnea in adults. JAMA 2004, 291:2013-2016.

3. Guilleminault C, Tilkian A, Dement WC: The sleep apnea syndromes. Annu Rev Med 1976, 27:465-484.

4. Somers VK, Dyken ME, Clary MP, Abboud FM: Sympathetic neural mechanisms in obstructive sleep apnea. J Clin Invest 1995, 96:1897-1904. 
5. Kato M, Roberts-Thomson P, Phillips BG, et al: Impairment of endotheliumdependent vasodilation of resistance vessels in patients with obstructive sleep apnea. Circulation 2000, 102:2607-2610.

6. Ross R: Atherosclerosis: an inflammatory disease. N Engl J Med 1999, 340:115-126.

7. Glass CK, Witztum JL: Atherosclerosis: the road ahead. Cell 2001, 104:503-516

8. Nieto FJ, Young TB, Lind BK, et al: Association of sleep-disordered breathing, sleep apnea, and hypertension in a large community-based study. Sleep Heart Health. JAMA 2000, 283:1829-1836.

9. Peppard PE, Young T, Palta M, et al: Prospective study of the association between sleep-disordered breathing and hypertension. $N$ Engl J Med 2000, 342:1378-1384.

10. Shahar E, Whitney CW, Redline S, Lee ET, Newman AB, Javier Nieto F, O'Connor GT, Boland LL, Schwartz JE, Samet JM: Sleep-disordered breathing and cardiovascular disease: cross-sectional results of the Sleep Heart Health Study. Am J Respir Crit Care Med 2001, 163:19-25.

11. Peker $Y$, Hedner J, Norum J, Kraiczi H, Carlson J: Increased incidence of cardiovascular disease in middle-aged men with obstructive sleep apnea: a 7-year follow-up. Am J Respir Crit Care Med 2002, 166:159-165.

12. Imadojemu VA, Gleeson K, Gray KS, Sinoway LI, Leuenberger UA: Obstructive sleep apnea during sleep is associated with peripheral vasoconstriction. Am J Respir Crit Care Med 2002, 165:61-66.

13. Sajkov D, Wang T, Saunders NA, Bune AJ, McEvoy RD: Continuous positive airway pressure treatment improves pulmonary hemodynamics in patients with obstructive sleep apnea. Am J Respir Crit Care Med 2002, 166:152-158.

14. Amin RS, Kimball TR, Bean JA, Jeffries JL, Willging JP, Cotton RT, Witt SA, Glascock BJ, Daniels SR: Left ventricular hypertrophy and abnorma ventricular geometry in children and adolescents with obstructive sleep apnea. Am J Respir Crit Care Med 2002, 165:1395-1399.

15. Sekosan M, Zakkar M, Wenig BL, Olopade CO, Rubenstein I: Inflammation in the uvula mucosa of patients with obstructive sleep apnea. Laryngoscope 1996, 106:1018-1020.

16. Bergeron C, Kimoff J, Hamid Q: Images in allergy and immunology: obstructive sleep apnea syndrome and inflammation. J Allergy Clin Immunol 2005, 116:1393-1396.

17. Puig F, Rico F, Almendros I, Montserrat JM, Navajas D, Farre R: Vibration enhances interleukin- 8 release in a cell model of snoring induced airway inflammation. Sleep 2005, 28:1312-1316.

18. Yokoe $T$, Minoguchi $K$, Matsuo $H$, Oda N, Minoguchi $H$, Yoshino $G$, et al: Elevated levels of C-reactive protein and interleukin- 6 in patients with obstructive sleep apnea syndrome are decreased by nasal continuous positive airway pressure. Circulation 2003, 107:1129-1134.

19. Shamsuzzaman ASM, Winnicki M, Lanfranchi $P$, Wolk R, Kara T, Accurso V, Somers VK: Elevated C - reactive protein in patients with obstructive sleep apnea. Circulation 2002, 105:2462-2464.

20. Kokturk O, Ciftci TU, Mollarecep E, Ciftci B: Elevated C-reactive protein levels and increased cardiovascular risk in patients with obstructive sleep apnea syndrome. Int Heart J 2005, 46:801-809.

21. Ursavaş A, Karadağ M, Rodoplu E, Yilmaztepe A, Oral HB, Gözü RO: Circulating ICAM-1 and VCAM-1 levels in patients with obstructive sleep apnea syndrome. Respiration 2007, 74:525-532.

22. von Känel R, Loredo JS, Ancoli-Israel S, Mills PJ, Natarajan L, Dimsdale JE: Association between polysomnographic measures of disrupted sleep and prothrombotic factors. Chest 2007, 131:733-739.

23. Punjabi NM, Beamer BA: C-reactive protein is associated with sleep disordered breathing independent of adiposity. Sleep 2007, 30:29-34.

24. de la Pena Bravo M, Serpero LD, Barcelo A, et al: Inflammatory proteins in patients with obstructive sleep apnea with and without daytime sleepiness. Sleep Breath 2007, 11:177-185.

25. Minoguchi K, Tazaki T, Yokoe T, et al: Elevated production of tumor necrosis factor- $a$ by monocytes in patients with obstructive sleep apnea syndrome. Chest 2004, 126:1473-1479.

26. Ciftci TU, Korturk O, Bukan $\mathrm{N}$, et al: The relationship between serum cytokine levels with obesity and obstructive sleep apnea syndrome. Cytokine 2004, 28:87-91.

27. Vgontzas AN, Papanicolaou DA, Bixler EO, Kales A, Tyson K, Chrousos GP. Elevation of plasma cytokines in disorders of excessive daytime sleepiness: role of sleep disturbance and obesity. J Clin Endocrinol Metab 1997, 82:1313-1316.
28. Vgontzas AN, Papanicolaou DA, Bixler EO, Hopper K, Lotsikas A, Lin HM, Kales A, Chrousos GP: Sleep apnea and daytime sleepiness and fatigue: relation to visceral obesity, insulin resistance, and hypercytokinemia. J Endocrinol Metab 2000, 85:1151-1158.

29. Liu H, Liu J, Xiong S, Shen G, Zhang Z, Xu Y: The change of interleukin- 6 and tumor necrosis factor in patients with obstructive sleep apnea syndrome. J Tongji Med Univ 2000, 20:200-202.

30. Barceló A, Barbé F, Llompart E, Mayoralas LR, Ladaria A, Bosch M, et al: Effects of obesity on C-reactive protein level and metabolic disturbances in male patients with obstructive sleep apnea. Am J Respir Crit Care Med 2004, 117:118-121.

31. Guilleminault C, Kirisoglu C, Ohayon MM: C-reactive protein and sleepdisordered breathing. Sleep 2004, 27:1507-1511.

32. Castell J, Gomez-Lechion M, David M: Acute phase response of human hepatocyte: regulation of acute-phase protein synthesis by interleukin- 6 . Hepatology 1990, 12:1179-1186.

33. Pasulka P, Bristian BR, Blackburn GL: Obesity and erythrocyte sedimentation rates. Ann Intern Med 1985, 103:304.

34. Roytblat L, Rachinsky M, Fisher A, Greemberg L, Shapira Y, Douvdevani A, et al: Raised interleukin-6 levels in obese patients. Obes Res 2000 , 8:673-675.

35. Meier-Ewert HK, Ridker PM, Rifai N, et al: Absence of diurnal variation of C-reactive protein concentrations in healthy human subjects. Clin Chem 2001, 47:426-430

36. Jialal I, Devaraj S, Venugopal SK: C-reactive protein: risk marker or mediator in atherothrombosis? Hypertension 2004, 44:6-11.

37. Calabro P, Willerson JT, Yeh ET: Infl ammatory cytokines stimulated C-reactive protein production by human coronary artery smooth muscle cells. Circulation 2003, 108:1930-1932.

38. Devaraj S, Xu DY, Jialal I: C-reactive protein increases plasminogen activator inhibitor-1 expression and activity in human aortic endothelial cells: implications for the metabolic syndrome and atherothrombosis. Circulation 2003, 107:398-404.

39. Han KH, Hong KH, Park JH, Ko J, Kang DH, Choi KJ, et al: C-reactive protein promotes monocyte chemoattractant protein-I-mediated chemotaxis through upregulating CC chemokine receptor 2 expression in human monocytes. Circulation 2004, 109:2566-2571.

40. Fichlscherer S, Breuer S, Schachinger V, Dimmeler S, Zeiher AM: C-reactive protein levels determine systemic nitric oxide bioavailability in patients with coronary artery disease. Eur Heart J 2004, 25:1412-1418.

41. Ridker PM: High-sensitivity C-reactive protein: potential adjunct for global risk assessment in the primary prevention of cardiovascular disease. Circulation 2001, 103:1813-1818.

42. Danesh J, Whincup P, Walker $M$, et al: Low grade inflammation and coronary heart disease: prospective study and updated meta-analyses. BMJ 2000, 321:199-204.

43. Ridker PM: Clinical application of C-reactive protein for cardiovascular disease detection and prevention. Circulation 2003, 107:363-369.

44. Lindahl B, Toss $H$, Siegbahn A, et al: Markers of myocardial damage and inflammation in relation to long-term mortality in unstable coronary artery disease. FRISC study group. Fragmin during instability in coronary artery disease. N Engl J Med 2000, 343:1139-1147.

45. Ridker PM, Rifai N, Pfeffer MA, et al: Long-term effects of pravastatin on plasma concentration of C-reactive protein. The Cholesterol and Recurrent Events (CARE) Investigators. Circulation 1999, 100:230-235.

46. Yudkin JS: kumari M, Humphries SE, Mohamed-Ali V. Infl ammation, obesity, stress and coronary heart disease: is interleukin- 6 the link? Atherosclerosis 2000, 148:209-214

47. Harris TB, Ferruci L, Tracy RP, Corti MC, Wacholder S, Ettinger WH Jr, et al: Association of elevated interleukin- 6 and C-reactive protein levels with mortality in the elderly. Am J Med 1999, 106:506-512.

48. Aderka D: The potential biological and clinical significance of the soluble tumor necrosis factor receptors. Cytokine Growth Factor Rev 1996, 7:231-240.

49. Brockhaus M, Schoenfeld H, Schlaeger E, Hunziker W, Lesslauer W, Loetscher $\mathrm{H}$ : Identification of two types of tumor necrosis factor receptors on human cell lines by monoclonal antibodies. Proc Natl Acad Sci USA 1990 87:3127-3131

50. Vgontzas AN, Papanicolaou DA, Bixler EO, et al: Circadian interleukin-6 secretion and quantity and depth of sleep. J Clin Endocrinol Metab 1999, $84: 2603-2607$ 
51. Peled N, Greenberg A, Pillar G, et al: Contributions of hypoxia and respiratory disturbance index to sympathetic activation and blood pressure in obstructive sleep apnea syndrome. Am J Hypertens 1998 11:1284-1289.

52. Malhotra A, Ayas NT, Epstein LJ: The art and science of continuous positive airway pressure therapy in obstructive sleep apnea. Curr Opin Pulm Med 2000, 6:490-495.

53. Patel SR, White DP, Malhotra A, et al: Continuous positive airway pressure therapy for treating sleepiness in a diverse population with obstructive sleep apnea: results of a meta-analysis. Arch Intern Med 2003, 163:565-571.

54. D'Ambrosio C, Bowman T, Mohsenin V: Quality of life in patients with obstructive sleep apnea: effect of nasal continuous positive airway pressure - a prospective study. Chest 1999, 115:123-129.

55. Milleron O, Pilliere R, Foucher A, et al: Benefits of obstructive sleep apnoea treatment in coronary artery disease: a long-term follow-up study. Eur Heart 2004, 25:728-734.

56. Sackett DL, Straus SE, Richardson WS, Rosenberg W, Haynes RB: Evidence base Medicine-How to practice and teach EBM. 2nd edition. Oxford: Churchill Livingstone; 2000:173-175.

57. Hozo SP, Djulbegovic B, Hozo I: Estimating the mean and variance from the median, range, and the size of a sample. BMC medical research methodology 2005, 5:13.

58. Patruno V, Aiolfi S, Costantino G, Murgia R, Selmi C, Malliani A, Montano N: Fixed and autoadjusting continuous positive airway pressure treatments are not similar in reducing cardiovascular risk factors in patients with obstructive sleep apnea. Chest 2007, 131(5):1393-1399.

59. Phillips CL, Yang Q, Williams A, Roth M, Yee BJ, Hedner JA, Berend N, Grunstein RR: The effect of short-term withdrawal from continuous positive airway pressure therapy on sympathetic activity and markers of vascular inflammation in subjects with obstructive sleep apnoea. J Sleep Res 2007, 16(2):217-225.

60. Tamaki S, Yamauchi M, Fukuoka A, Makinodan K, Koyama N, Tomoda K, Yoshikawa M, Kimura $\mathrm{H}$ : Production of inflammatory mediators by monocytes in patients with obstructive sleep apnea syndrome. Intern Med 2009, 48(15):1255-1262.

61. Schiza SE, Bouloukaki I, Mermigkis C, Panagou P, Tzanakis N, Moniaki V, Tzortzaki E, Siafakas NM: C-reactive protein evolution in obstructive sleep apnoea patients under CPAP therapy. Eur J Clin Invest 2010, 40(11):968-975.

62. Mermigkis C, Bouloukaki I, Mermigkis D, Kallergis E, Mavroudi E, Varouchakis G, Tzortzaki E, Siafakas N, Schiza SE: CRP evolution pattern in CPAP-treated obstructive sleep apnea patients. Does gender play a role? Sleep Breath 2012, 16(3):813-819.

63. Carniero G, Togeiro SM, Ribeiro-Filho FF, Truksinas E, Ribeiro AB, Zanella MT, Tufik S: Continuous positive airway pressure therapy improves hypoadiponectinemia in severe obese men with obstructive sleep apnea without changes in insulin resistance. Metab Syndr Relat Disord 2009, 7(6): 537-542.

64. Chung S, Yoon IY, Lee CH, Kim JW: The effects of nasal continuous positive airway pressure on vascular functions and serum cardiovascular risk factors in obstructive sleep apnea syndrome. Sleep Breath 2011, 15(1):76-81.

65. Colish J, Walker JR, Elmayergi N, Almutairi S, Alharbi F, Lytwyn M, Francis A, Bohonis S, Zeqlinski M, Kirkpatrick ID, Sharma S, Jassal DS: Obstructive sleep apnea: effects of continuous positive airway pressure on cardiac remodeling as assessed by cardiac biomarkers, echocardiography, and cardiac MRI. Chest 2012, 141(3):674-681.

66. Dorkova Z, Petrasova D, Molcayiova A, Popovnakova M, Tkacova R: Effects of continuous positive airway pressure on cardiovascular risk profile in patients with severe obstructive sleep apnea and metabolic syndrome. Chest 2008, 134(4):686-692.

67. Harsch IA, Koebnick C, Wallaschofski H, Schahin SP, Hahn EG, Ficker JH, Lohmann T, Konturek PC: Resistin levels in patients with obstructive sleep apnoea syndrome - the link to subclinical inflammation? Med Sci Monit 2004, 10(9):CR510-5.

68. lesato K, Tatsumi K, Saibara T, Nakamura A, Terada J, Tada Y, Sakao S, Tanabe N, Takiguchi Y, Kuriyama T: Decreased lipoprotein lipase in obstructive sleep apnea syndrome. Circ J 2007, 71(8):1293-8.

69. Ishida K, Kato M, Kato Y, Yanagihara K, Kinugasa Y, Kotani K, Igawa O, Hisatome I, Shigemasa C, Somers VK: Appropriate use of nasal continuous positive airway pressure decreases elevated C-reactive protein in patients with obstructive sleep apnea. Chest 2009, 136(1):125-129.
70. Ryan S, Nolan GM, Hannigan E, Cunningham S, Taylor C, McNicholas WT: Cardiovascular risk markers in obstructive sleep apnoea syndrome and correlation with obesity. Thorax 2007, 62(6):509-514.

71. Steiropoulos P, Tsara V, Nena E, Fitili C, Kataropoulou M, Froudarakis M, Christaki P, Bouros D: Effect of continuous positive airway pressure treatment on serum cardiovascular risk factors in patients with obstructive sleep apnea-hypopnea syndrome. Chest 2007, 132(3):843-851.

72. Zhao Q, Liu ZH, Zhao ZH, Luo Q, McEvoy RD, Zhang HL, Wang Y: Effects of obstructive sleep apnea and its treatment on cardiovascular risk in CAD patients. Respir Med 2011, 105(10):1557-1564.

73. Arias MA, García-Río F, Alonso-Fernández A, Hernanz A, Hidalgo R, MartínezMateo V, Bartolomé S, Rodríguez-Padial L: CPAP decreases plasma levels of soluble tumour necrosis factor-alpha receptor 1 in obstructive sleep apnoea. Eur Respir J 2008, 32(4):1009-1015.

74. Guasti L, Marino F, Cosentino M, Maroni L, Maresca AM, Colombo F, Maio RC, Castiglioni L, Saporiti F, Loraschi A, Gaudio G, Bernasconi A, Laurita E, Grandi AM, Venco A: Cytokine production from peripheral blood mononuclear cells and polymorphonuclear leukocytes in patients studied for suspected obstructive sleep apnea. Sleep Breath 2011, 15(1):3-11.

75. Ryan S, Taylor CT, McNicholas WT: Selective activation of inflammatory pathways by intermittent hypoxia in obstructive sleep apnea syndrome. Circulation 2005, 112(17):2660-2667.

76. Ryan S, Taylor CT, McNicholas WT: Predictors of elevated nuclear factorkappaB-dependent genes in obstructive sleep apnea syndrome. Am J Respir Crit Care Med 2006, 174(7):824-830.

77. Steiropoulos P, Kotsianidis I, Nena E, Tsara V, Gounari E, Hatzizisi O, Kyriazis G, Christaki P, Froudarakis M, Bouros D: Long-term effect of continuous positive airway pressure therapy on inflammation markers of patients with obstructive sleep apnea syndrome. Sleep 2009, 32(4):537-543.

78. Vgontzas AN, Zoumakis E, Bixler EO, Lin HM, Collins B, Basta M, Pejovic S, Chrousos GP: Selective effects of CPAP on sleep apnoea-associated manifestations. Eur J Clin Invest 2008, 38(8):585-595.

79. Burioka N, Miyata M, Fukuoka Y, Endo M, Shimizu E: Day-night variations of serum interleukin- 6 in patients with severe obstructive sleep apnea syndrome before and after continuous positive airway pressure (CPAP). Chronobiol Int 2008, 25(5):827-834.

80. Ye L, Ma GH, Chen L, Li M, Liu JL, Yang K, Li QY, Li N, Wan HY: Quantification of circulating cell-free DNA in the serum of patients with obstructive sleep apnea-hypopnea syndrome. Lung 2010, 188(6):469-474.

81. Sharma SK, Kumpawat S, Goel A, Banga A, Ramakrishnan L, Chaturvedi P: Obesity, and not obstructive sleep apnea, is responsible for metabolic abnormalities in a cohort with sleep disordered breathing. Sleep Med 2007, 8(1):12-17.

82. Kohler M, Ayers L, Pepperell JC, Packwood KL, Ferry B, Crosthwaite N, Craig S, Siccoli MM, Davies RJ, Stradling JR: Effects of continuous positive airway pressure on systemic inflammation in patients with moderate to severe obstructive sleep apnoea: a randomized controlled trial. Thorax 2009, 64(1):67-73

doi:10.1186/1476-9255-10-13

Cite this article as: Baessler et al:: Treatment for sleep apnea by continuous positive airway pressure improves levels of inflammatory markers - a meta-analysis. Journal of Inflammation 2013 10:13.

\section{Submit your next manuscript to BioMed Central and take full advantage of:}

- Convenient online submission

- Thorough peer review

- No space constraints or color figure charges

- Immediate publication on acceptance

- Inclusion in PubMed, CAS, Scopus and Google Scholar

- Research which is freely available for redistribution 